\title{
Marta Mulawa
}

Uniwersytet Marii Curie-Skłodowskiej w Lublinie

martamulawa@interia.pl

\section{Podmiotowość prawna gminy - analiza wybranych zagadnień}

\section{Legal Subjectivity of Community - Analysis of Selected Issues}

\section{STRESZCZENIE}

Podmiotowość publicznoprawna gminy stanowi istotne zagadnienie już od czasów II Rzeczypospolitej. W obecnie obowiązującym porządku prawnym podmiotowość prawna gminy dalej jest przedmiotem dyskusji. Mimo że Konstytucja RP nie wskazuje expressis verbis sformułowania podmiotowości publicznoprawnej gminy, wynika ona z analizy norm konstytucyjnych określających jej zakres i sposób działania. Podmiotowość publicznoprawna gminy jest zakorzeniona w Konstytucji RP. Akt ten określa gminę jako podmiot publiczny, ukazując także zasady będące gwarantem jej podmiotowości.

Słowa kluczowe: gmina; podmiotowość prawna; podmiot publiczny; jednostka samorządu terytorialnego; korporacja lokalna

\section{WSTĘP}

Zagadnienie podmiotowości publicznoprawnej gminy od czasów II Rzeczypospolitej było przedmiotem licznych kontrowersji. W konsekwencji ta sytuacja doprowadziła do sporów między przedstawicielami prawa publicznego. Polskie prawo nie uregulowało dokładnie tego zagadnienia. Dopiero reaktywacja samorządu w $1990 \mathrm{r}$. wpłynęła na ponowne zainteresowanie tym pojęciem. Preferowano podmiotowe traktowanie władz lokalnych, uznając odrębność celów, którym służy ich działalność ${ }^{1}$. Istotna stała się kwestia uznania odrębności interesów lokalnych

${ }^{1}$ Model wladzy lokalnej $w$ systemie reformy gospodarczej, red. M. Kulesza, t. 5, Warszawa 1985, s. 5. 
od ogólnospołecznych, czego efektem byłaby instytucjonalizacja pozycji władzy lokalnej w tej kwestii. Odrębna podmiotowość prawna jednostek samorządowych miała stanowić prawny wyraz tego stanu².

Obecnie podmiotowość prawna gminy dalej jest przedmiotem dyskusji. Mimo że Konstytucja $\mathrm{RP}^{3}$ nie wskazuje expressis verbis sformułowania podmiotowości publicznoprawnej gminy, wynika ona $\mathrm{z}$ analizy norm konstytucyjnych określających jej zakres i sposób działania.

Niezwykle istotny dla określenia podmiotowości publicznoprawnej gminy jest art. 15 ust. 1 Konstytucji RP, określający zasadę decentralizacji władzy publicznej. Ponadto nie bez znaczenia jest art. 16, który wskazuje, że naczelną zasadą ustrojową Rzeczypospolitej jest udział samorządu w sprawowaniu władzy publicznej i wykonywanie części zadań publicznych w imieniu własnym i na własną odpowiedzialność.

Zgodnie z art. 165 Konstytucji RP każda jednostka samorządu terytorialnego ma osobowość prawną, ponadto przysługuje jej prawo własności oraz inne prawa majątkowe. Osobowości prawnej gminy nie należy jednak utożsamiać tylko z osobowością w sferze prawa cywilnego. Art. 16 ust. 2 Konstytucji RP wskazuje, że samorząd uczestniczy w sprawowaniu władzy publicznej. Przysługującą mu w ramach ustaw istotną część zadań publicznych wykonuje w imieniu własnym i na własną odpowiedzialność, a więc w sposób samodzielny. Dlatego też problematyka odpowiedzialności gminy (jako osoby prawnej) za wykonywanie zadań publicznych świadczy o jej podmiotowości publicznoprawnej.

Instytucja samorządu terytorialnego $\mathrm{w}$ polskim porządku prawnym jest kluczowa. Konstytucja RP i ustawy określają jej formę i treść. W Konstytucji RP zakorzeniona jest podmiotowość publicznoprawna gminy. Powyższy akt normatywny określa ją jako podmiot publiczny, ukazując także zasady będące gwarantem jej podmiotowości.

Gmina jako podmiot prawa publicznego jest wyodrębniona instytucjonalnie i funkcjonalnie. Podmiotowość publicznoprawna świadczy o jej odrębnym statusie jako korporacji lokalnej. Instytucjonalne i funkcjonalne wyodrębnienie wynika z obowiązującej Konstytucji RP. Świadectwem oddzielnego organizacyjnego statusu korporacji lokalnej jest podmiotowość publicznoprawna.

2 M. Kulesza, Władza lokalna w systemie reformy gospodarczej, „Państwo i Prawo” 1983, nr 3, s. 86 .

3 Konstytucja Rzeczypospolitej Polskiej z dnia 2 kwietnia 1997 r. (Dz.U. 1997, nr 78, poz. 483 ze zm.), dalej jako: Konstytucja RP. 


\section{PODMIOTOWOŚĆ GMINY W OBOWIĄZUJĄCYM PORZĄDKU PRAWNYM}

Niewątpliwie podmiotowość publicznoprawna gminy ma wpływ na określenie pozycji samorządu gminnego na gruncie polskiego systemu prawnego. Dzięki przemianom ustrojowym w 1989 r. doszło do zmian zasad konstytucyjnych. Ustawa o samorządzie terytorialnym ${ }^{4}$ wprowadziła unormowania dotyczące funkcjonowania i organizacji powstającego samorządu. Podążając za zasadą decentralizacji, ustawodawca dokonał przeniesienia części władzy na gminy, które posiadają podmiotowość prawną odrębną od podmiotowości Skarbu Państwa czy innych osób prawnych.

Gminy dysponują oddzielną od państwa podmiotowością publicznoprawną i osobowością prawną. Stanowią one korporacje prawa publicznego i wykonują zadania publiczne we własnym imieniu, samodzielnie.

W celu zapewnienia samodzielności władzy lokalnej kształtów właściwych dla samorządu terytorialnego niezbędne jest odpowiednie wyodrębnienie podmiotowe. Wiąże się ono ze stosownymi zadaniami, kompetencjami, które służą realizacji celów zdefiniowanych ustawowo.

W obowiązującym porządku prawnym trudno odnaleźć przepis prawny posługujący się terminem osobowości prawnej, dlatego jest to pojęcie teoretycznoprawne, nie można wskazać zatem jego treści normatywnej. $j^{5}$ Ustawodawca nie porusza problematyki osobowości prawnej gminy. Biorąc jednak pod uwagę przypisane gminie atrybuty, można stwierdzić, iż gmina funkcjonuje jako podmiot w sferze prawa publicznego. Konstytucja natomiast nie posługuje się wprost tym sformułowaniem. Charakter osobowości prawnej gminy także nie został dokładnie sprecyzowany.

Można wskazać istnienie podmiotowości prawnej gminy oraz jej osobowości, mając na względzie postanowienia konstytucyjne i ustawowe, a także jej atrybuty. Biorąc pod uwagę podział administracyjny państwa, gmina stanowi odrębny podmiot prawa dysponujący władztwem publicznym. Dzięki odrębnej podmiotowości gminy jej organy mogą wstępować w stosunki prawne z innymi organami. Wypływa to przede wszystkim z osobowości prawnej ${ }^{6}$.

${ }^{4}$ Ustawa z dnia 8 marca 1990 r. o samorządzie terytorialnym (Dz.U. 1990, nr 16, poz. 95 ze zm.), dalej jako: u.s.g. (obecny tytuł ustawy: o samorządzie gminnym). Stosownie do art. 10 ustawy z dnia 29 grudnia 1998 r. (Dz.U. 1998, nr 162, poz. 1126) niniejsza ustawa została zmieniona ustawą z dnia 8 lipca 2005 r. o zmianie ustawy o samorządzie gminnym oraz niektórych innych ustaw (Dz.U. 2005, nr 175, poz. 1457) z dniem rozpoczęcia kadencji wójtów (burmistrzów, prezydentów miast) następującej po kadencji, w czasie której została ogłoszona ustawa zmieniająca.

5 A. Wiktorowska, Prawne determinanty samodzielności gminy. Zagadnienia administracyjnoprawne, Warszawa 2002, s. 79.

6 S. Wójcik, Samorząd terytorialny w Polsce w XX w. Myśl samorządowa, historia i współczesność, Lublin 1999, s. 191. 
O wszelkich nieporozumieniach na linii administracja rządowa i samorządowa możemy mówić, zakładając, iż gmina stanowi podmiot prawa publicznego. Ustawodawca gwarantuje prawną możliwość przeciwstawienia woli działających organów na rzecz gminy woli organów administracji rządowej. Z pewnością wpływa to na ochronę lokalnego interesu oraz większą swobodę czy samodzielność w wykonywaniu zadań przez gminę. Ponadto wola ta nie może w żaden sposób naruszać obowiązującego porządku prawnego ${ }^{7}$.

Należy zaznaczyć, iż do gmin odnosi się zarówno zagadnienie podmiotowości publicznoprawnej, jak i osobowości. Osobowość prawna gminy jest jednorodna. Występuje w sferze prawa prywatnego i publicznego. Jej istotą jest stawanie się podmiotem praw i obowiązków tak w sferze prawa publicznego, jak i prywatnego. Osobowość publicznoprawna gminy wpływa na jej podmiotowy charakter na gruncie prawa publicznego.

Bazując na obowiązujących regulacjach prawnych, wskazuje się, że istnieje podmiotowość prawna gmin w zakresie spraw majątkowych i spraw uregulowanych normami prawa publicznego ${ }^{8}$. Podkreśla się jednak, iż osobowość prawna gminy w sferze prawa publicznego jest bardziej problematyczna niż cywilnoprawna. Wskazuje się pewne fakty prawne, które umożliwiają uznanie podmiotowego charakteru gminy. Można wśród nich wyróżnić: występowanie interesów lokalnych odrębnych od celów ogólnopaństwowych, odpowiedzialność wiążącą się z zaspokajaniem potrzeb lokalnych, utożsamianie władzy lokalnej z lokalnymi interesami, umożliwienie ochrony lokalnych potrzeb czy interesów przez stworzenie gwarancji formalnoprawnych, zmniejszenie ingerencji organów nadzorczych ${ }^{9}$.

\section{2. ŚWIADECTWO PODMIOTOWOŚCI PUBLICZNOPRAWNEJ GMINY}

Przejawem podmiotowości publicznoprawnej gminy jest prawo gminy będącej osobą prawną do określania w statucie swojej struktury organizacyjnej, zakresu i sposobu działania. Statut jest aktem pochodnym, uzupełniającym wobec przepisów u.s.g. Nie powinien zawierać postanowień z nią sprzecznych czy też powielać jej zapisów. Stanowi dokument zawierający szereg przepisów dotyczących zakresu działania i zadań gminy. Oprócz przepisów dotyczących organizacji wewnętrznej rady gminy i jej komisji, pracy wójta, zawiera także te odnoszące się do jednostek pomocniczych, organizacyjnych. Określa ponadto zasady gospodarki finansowej gminy, definiuje pojęcie mienia komunalnego. Istotną częścią statutu są załączniki

7 M. Zdyb, Samorzą a państwo. Nadzór nad samorządem terytorialnym, Lublin 1993, s. 30.

8 B. Zawadzka, Glosa do orzeczenia TK z dnia 24 stycznia 1995 r., K 5/94, „Państwo i Prawo” 1995, z. 4, s. 96.

9 M. Stahl, Poszukiwania modelu władzy i administracji lokalnej w Polsce, Łódź 1989, s. 53. 
zawierające mapę gminy, opis herbu, flagi gminy, wykaz gminnych jednostek organizacyjnych czy wykaz jednostek pomocniczych gminy. Podejmując różnorodne czynności prawne i faktyczne (m.in. prowadzenie gospodarki w oparciu o własny budżet, ustalanie podatków, opłat lokalnych), gmina dysponuje samodzielnością w działaniu, co należy wiązać z brakiem jej podporządkowania $\mathrm{w}$ granicach ustaw woli innego podmiotu. Ustawa o finansach publicznych ${ }^{10}$ odrzuca jednak możliwość nieskrępowanego decydowania o dochodach, źródłach ich pozyskiwania i wykorzystywania przez gminę.

Sprawując nadzór nad samorządem, państwo nie może wkraczać w sferę przyznanej jej podmiotowości publicznoprawnej. Samorząd, wykonując zadania, może podejmować je w sposób swobodny, zaś nadzór sprawowany przez organy rządowe - zgodnie z art. 171 ust. 1 - powinien ograniczyć się tylko do kontroli legalności. Nadzór ma przede wszystkim zapewnić koordynację działalności gminy z obowiązującym porządkiem prawnym. W przypadku naruszenia przyznanego gminie zakresu podmiotowości, dysponuje ona możliwością obrony przed ingerencją nadzorczą w postaci skargi do sądu administracyjnego. Z kolei w sytuacji naruszenia praw podmiotowych gminy przez inny podmiot, przysługuje jej dochodzenie swoich praw na drodze sądowej. Możliwość taka stanowi potwierdzenie charakteru podmiotowego gminy na gruncie prawa publicznego.

Warto także wspomnieć o działalności gospodarczej gminy oraz jej osób prawnych, która jest prowadzona na podstawie własności komunalnej. Przyznane gminie w art. 165 Konstytucji RP prawo własności i inne prawa majątkowe stanowią materialną podstawę gwarancji jej podmiotowości prawnej.

Realizując zadania lokalne w sposób samodzielny, niezastrzeżony ustawami na rzecz innych podmiotów, osiągając cele w imieniu własnym i na własną odpowiedzialność, gmina dysponuje pewnymi przywilejami. Można wśród nich wskazać władztwo finansowe, organizacyjne, planistyczne, prowadzenie polityki personalnej, wydawanie przepisów miejscowych. Należy pamiętać, że samodzielność ta wiąże się z odpowiedzialnością gminy, co wpływa na formowanie jej podmiotowości.

Ważne jest wprowadzenie pewnych przesłanek dotyczących odpowiedzialności za szkody podczas korzystania z władztwa administracyjnego przez gminy, np. powołanie się na zapis konstytucyjny: „Każdy ma prawo do wynagrodzenia szkody, jaka została mu wyrządzona przez niezgodne z prawem działanie organu władzy publicznej" - co wskazuje na realizację zasady legalizmu (art. 7 Konstytucji RP). Odpowiedzialność wiąże się zatem z niezgodnym z prawem działaniem lub zaniechaniem jako źródłem szkody. Gmina ponosi również odpowiedzialność majątkową (na zasadach ogólnych prawa cywilnego) i jest obowiązana do naprawienia szkody.

${ }^{10}$ Ustawa z dnia 27 sierpnia 2009 r. o finansach publicznych (Dz.U. 2009, nr 157, poz. 1240 ze zm), dalej jako: u.f.p. 
Odszkodowanie dla podmiotu dotkniętego niezgodnym z prawem działaniem powinno obejmować pełną wysokość szkody. Konieczne jest zatem uwzględnienie, oprócz strat materialnych, strat moralnych poniesionych w wyniku bezprawnych działań urzędniczych ${ }^{11}$.

Podmiotowość gminy realizuje się w wyniku przyznania jej praw podmiotowych. Wykonuje ona zadania o charakterze publicznym, dysponując władczymi formami działania ${ }^{12}$. Prawa te wpływają na powstanie sfery samodzielności gminy ${ }^{13}$. Prawa podmiotowe gminy to:

- sytuacja prawna określona przez normę prawa stanowionego, powstająca na podstawie normy tego prawa lub wymagająca wydania stosownego aktu indywidualnego, upatrująca źródła w prawie przedmiotowym,

- podmiotem normy jest gmina,

- gmina jest wyposażona w określone roszczenie mające na celu określone zachowanie służące interesowi lokalnemu lub też żądanie nieingerencji w określone sfery ${ }^{14}$.

\section{WAGA PODMIOTOWOŚCI PUBLICZNOPRAWNEJ GMINY}

Przywrócenie podmiotowości publicznoprawnej gminie dzięki reaktywowaniu samorządu terytorialnego w 1990 r. ożywiło trwające na ten temat dyskusje. Ustrojodawca wyposażył gminę w odpowiednie atrybuty, ale stosując metodę opisową, nie wskazał sformułowania expressis verbis.

Status ustrojowy samorządu bazuje na odrębnej od państwa podmiotowości w prawie publicznym, gwarantując mu przy tym samodzielność w wykonywaniu zadań publicznych, także tych ujętych w prawie pozytywnym pod postacią klauzuli generalnej ${ }^{15}$. Bazę do podejmowania przez gminę samodzielnych działań organizatorskich i wykonawczych stanowi art. 6 i art. 7 ust. 1 u.s.g.

Prawnopozytywne podstawy działania samorządu możemy odnaleźć w jednej z uchwał Trybunału Konstytucyjnego, w której wskazuje on, iż

${ }^{11}$ Wyrok Trybunału Konstytucyjnego z dnia 23 września 2003 r., K 20/02, OTK ZU 2003, nr 7A, poz. 76 .

${ }^{12}$ T. Dybowski, Mienie komunalne, [w:] Samorzad terytorialny, red. A. Piekara, Z. Niewiadomski, Warszawa 1998, s. 266.

${ }_{13}$ J. Boć, Konstytucje Rzeczypospolitej oraz komentarz do Konstytucji RP z 1997 r., Wrocław 1998, s. 258.

${ }^{14}$ W. Jakimowicz, Publiczne prawa podmiotowe, Kraków 2002, s. 246.

${ }^{15} \mathrm{M}$. Kulesza, O tym, ile jest decentralizacji w centralizacji, a także o osobliwych nawykach uczonych administratywistów, „Samorząd Terytorialny” 2009, nr 12, s. 7. 
[...] gwarantując samorządowi terytorialnemu udział w sprawowaniu władzy oraz powierzając implicite organom państwa określenie rozmiarów i form tego udziału, polski ustawodawca konstytucyjny ustanowił prawnopozytywne podstawy działania samorządu terytorialnego i włączył go w struktury sprawowania władzy w demokratycznym państwie prawnym, a tym samym odmówił mu przymiotu władzy suwerennej, o innym niż prawo stanowione przez to państwo - źródle władzy publicznej ${ }^{16}$.

Konstrukcja podmiotowości publicznoprawnej w polskim ustawodawstwie i doktrynie nie jest używana wprost lub jest stosowana rzadko. W systemie zdecentralizowanym podmiotowość stanowi podstawową formułę określającą status podmiotu w prawie publicznym ${ }^{17}$. Podmiotowość publicznoprawna nie odnosi się do kompetencji podmiotu, osobowości prawnej, ale do zakresu i charakteru odpowiedzialności publicznoprawnej podmiotu, która jest pełna i skutkowa ${ }^{18}$.

$\mathrm{Na}$ odrębną od państwa podmiotowość publicznoprawną wskazują zarówno Konstytucja RP, jak i Europejska Karta Samorządu Lokalnego ${ }^{19}$. Akty te podobnie ukazują kwestię odpowiedzialności samorządu:

- art. 16 ust. 2 Konstytucji RP podkreśla, że jednostki wykonują zadania publiczne w imieniu własnym i na własną odpowiedzialność,

- art. 3 ust. 1 EKSL wskazuje, że samorząd lokalny oznacza prawo i zdolność społeczności lokalnych - w granicach określonych prawem - do kierowania i zarządzania zasadniczą częścią spraw publicznych na ich własną odpowiedzialność i w interesie ich mieszkańców,

- art. 4 ust. 2 EKSL stanowi, że społeczności lokalne mają - w zakresie określonym prawem - pełną swobodę działania w każdej sprawie, która nie jest wyłączona z ich kompetencji lub nie wchodzi w zakres kompetencji innych organów władzy.

Istnieje przekonanie, $\mathrm{iz}$

[...] w prawie administracyjnym nie ma miejsca na koncepcję podmiotowości prawnej, która by miała oznaczać ogólnie określoną zdolność działania, traktowaną jako punkt wyjścia i przesłankę do podejmowania działań prawnych. Zamiast tego determinują szczegółowe normy prawa przedmiotowego sytuację prawną administracji państwowej i adresata jej działań.

${ }^{16}$ Uchwała Trybunału Konstytucyjnego z dnia 27 września 1994 r., W 10/93, OTK 1994, cz. 2 , poz. 46.

${ }^{17}$ M. Kulesza, O tym, ile jest decentralizacji..., s. 7.

${ }^{18}$ Ibidem.

${ }^{19}$ Europejska Karta Samorządu Terytorialnego sporządzona w Strasburgu dnia 15 października 1985 r. (Dz.U. 1994, nr 124, poz. 607). W 1994 r. Karta weszła do polskiego systemu prawnego pod nazwą Europejska Karta Samorządu Terytorialnego. W 2006 r. ówczesna minister spraw zagranicznych, Anna Fotyga, sprostowała nazwę na obecnie obowiązującą - Europejska Karta Samorządu Lokalnego (dalej jako: EKSL). 
Dlatego należy uznać sytuację prawną zarówno administracji państwowej, jak i jednostek za efekt obowiązywania ogółu norm prawa administracyjnego, które w obliczu określonych stanów faktycznych mają w odniesieniu do nich znajdować zastosowanie ${ }^{20}$.

Podmiotowość prawna gminy ma niezwykle istotną wagę. Wynika ona wprost z określonej w art. 16 Konstytucji RP zasady korporacjonizmu oraz osobowości prawnej, na co wskazuje art. 165 Konstytucji RP. Władztwo gminne umożliwia realizowanie zadań na rzecz wspólnoty lokalnej. Nie byłoby ono urzeczywistniane bez uznania osobowości prawnej w sferze prawa publicznego. Ich realizację umożliwia korzystanie ze środków prawnych (także o charakterze władczym) właściwych władzy państwowej.

Podejmując określone działania, organy samorządu winny określić, oprócz ich podstawy normatywnej, odpowiednie przepisy odnoszące się do konkretnej formy działania, z której korzystają. Należy pamiętać, że korzystanie przez organy gminy z władczej formy działania nie ma bezpośredniego związku z przyznaną jej osobowością prawną, ważna jest w tym momencie analiza prawa pozytywnego ${ }^{21}$. Mogłoby się jednak wydawać, iż wystarczającym uzasadnieniem dla uznania osobowości prawnej jest jej umocowanie konstytucyjne.

Gwarantem swobodnego zarządzania przez samorząd gminy własnymi, lokalnymi sprawami jest konstytucja, ustawy czy statut. Realizując zadania publiczne, samorząd nie może dysponować suwerennymi zadaniami czy prawami, gdyż to państwo jest suwerenem. Funkcjonowanie gminy w obrocie prawnym jest uzależnione od ustawodawcy, jego woli. Należy mieć na uwadze, iż gmina - podobnie jak państwo - jest podmiotem, który dysponuje osobowością prawną oraz wykonuje swoje zadania na podstawie i w granicach prawa.

Podmiotowość publicznoprawna gminy przesądza o jej miejscu w systemie państwa - zarówno politycznym, jak i prawnym. Stanowi zatem o jej pozycji wobec pozostałych podmiotów. Należy pamiętać, iż „podmiotem praw i obowiązków nie jest organ lub system organów ani gmina jako jednostka podziału terytorialnego lub odpowiednio zorganizowana grupa ludzi, lecz gmina jako odpowiednio zorganizowana wspólnota zamieszkała na określonym terytorium"22.

Samodzielność samorządu gminnego ma fundamentalne znaczenie w jego działalności. Można w tym momencie powołać się na odrębność majątkową, organizacyjną, sposób, w jaki realizuje on zadania czy niezależność organów gminy od organów administracji państwowej. Możliwość wykonywania w imieniu własnym i na własną odpowiedzialność zadań administracji publicznej świadczy

${ }^{20}$ J. Filipek, Prawo administracyjne. Instytucje ogólne, t. 1, Kraków 1995, s. 25.

${ }^{21}$ P. Przybysz, Wspótczesna teoria prawa administracyjnego wobec klasycznych konstrukcji pojęciowych, „Samorząd Terytorialny” 2000, nr 1-2, s. 62.

${ }^{22}$ M. Zdyb, op. cit., s. 30. 
przede wszystkim o jego samodzielności. Gmina korzysta z przyznanej jej władzy publicznej, lecz jej organy (które również korzystają z przypisanych im ustawowo kompetencji) nie należą do organów administracji państwowej.

Na formowanie podmiotowości gminy ma wpływ osobowość prawna. Wspomaga ona funkcjonowanie gminy w obrocie prawnym jako odrębnego podmiotu wpływającego na realizację interesu publicznego. Realizowanie przez gminę zadań publicznych we własnym imieniu i na własną odpowiedzialność uwydatnia podmiotowość publicznoprawną gminy. Gmina jako korporacja jest odpowiedzialna za wykonywanie tych zadań i sprawowanie władztwa administracyjnego.

Art. 163 Konstytucji RP wskazuje na domniemanie kompetencji samorządu, który wykonuje zadania publiczne niezastrzeżone dla organów innych władz publicznych, ale przede wszystkim gminy jako podstawowej jednostki samorządu terytorialnego, co wynika z art. 164 Konstytucji. Funkcjonujący model samorządu został skonstruowany na ściśle określonych zasadach: odrębności ustrojowej, odrębności zadaniowej, odrębności organizacyjnej.

W zakresie charakteru i pełnionych funkcji organy samorządu różnią się od organów państwowych. Prawo pozytywne jest źródłem funkcjonowania samorządu, jego odrębności, zatem źródłem władzy samorządowej jest wola mieszkańców i prawo powszechnie obowiązujące, w tym Konstytucja RP.

Samorząd wykonuje zadania publiczne niezastrzeżone przez Konstytucję czy ustawy na rzecz innych organów publicznych (administracji rządowej). Nie należy jednak absolutyzować tej zasady. Samorząd bowiem nie może funkcjonować w sposób dla niego zupełnie dogodny, zważając tylko na kwestię spraw lokalnych. Zadania powierzane samorządowi jako własne to takie, które: mają charakter publiczny, dotyczą spraw związanych z potrzebami lokalnymi, są realizowane w obrębie właściwości miejscowej jednostki ${ }^{23}$. U.s.g. nie wymienia enumeratywnie zadań własnych, umożliwiając rozszerzenie katalogu tych zadań. Wybiera tylko te najbardziej znaczące.

Warunkiem do podmiotowego spojrzenia na społeczności lokalne jest odpowiednie wyodrębnienie interesów lokalnych od państwowych. Kategoria interesu lokalnego ma charakter obiektywny, co znaczy, że interesy te występują realnie, niezależnie od tego, czy akceptuje to nauka prawa i czy uwzględnia je prawo pozytywne, a więc czy istnieją konstrukcje prawne umożliwiające prawidłową reprezentację i artykulację i wreszcie - realizację zbiorowych potrzeb miejscowej ludności. Problem nie dotyczy kwestii, czy owe interesy i potrzeby istnieją, lecz wyłącznie tego, czy i w jaki sposób problem ten jest rozwiązany w sferze normatywnej. Zaakceptowanie poglądów o odrębności celów lokalnych od ogólnopaństwowych i o konieczności uwzględnienia swoistości tych kategorii w obrocie

\footnotetext{
${ }^{23}$ Orzeczenie Trybunału Konstytucyjnego z dnia 23 października 1995 r., K 4/95, cz. 2, poz. 11.
} 
prawnym i w systemie zarządzania jest równoznaczne z podmiotowym „widzeniem" społeczności terytorialnej ${ }^{24}$.

Realizowanie interesu lokalnego danej zbiorowości jest bardzo ważne. Należy przy tym pamiętać, iż gmina ma określone prawa i obowiązki zarówno wobec mieszkańców, jak i państwa.

Wpływ na podmiotowość publicznoprawną gminy ma władcze wyrażanie swojej woli (stosowanie władztwa administracyjnego) przez gminę. Podmiotowość publicznoprawną gmin uwydatnia funkcjonowanie administracji rządowej i samorządowej.

Wachlarz kompetencji, jakim dysponuje gmina, wynika z podmiotowości prawnej gminy, ale nie należy kojarzyć jej z kompetencjami. Gmina jako podmiot prawa posiada osobowość prawną. Organy gminy posiadają kompetencje do realizowania zadań gminy w jej imieniu i na jej rachunek ${ }^{25}$. Konstytucja RP wraz z u.s.g. przyznają gminie osobowość prawną, która przesądza o wadze podmiotowości w całym systemie. Ponadto obowiązujące prawo wyznacza treść podmiotowości gminy. Niekiedy niezbędne są zabiegi interpretacyjne mające na celu dojście do odpowiedniej konkluzji w tym przedmiocie ${ }^{26}$.

\section{PODSUMOWANIE}

Jedną z najbardziej specyficznych cech podmiotowości prawnej gminy jest to, że wynika ona z norm prawa przedmiotowego, nie opiera się zaś na prawach przyrodzonych, właściwych gminie ${ }^{27}$. Obowiązujący porządek prawny wyznacza granice i treść tej podmiotowości. Podmiotowość prawną gminy należy analizować, mając na uwadze jej interes publiczny i odrębność od administracji rządowej. Jako podmiotowi administracji publicznej gminie przysługują zarówno publiczne prawa podmiotowe, jak i obowiązki.

Jako podmiot prawa publicznego gmina dysponuje atrybutami przesądzającymi o jej sytuacji prawnej, o traktowaniu jej jako podmiotu. Można wśród nich wyróżnić: sprawowanie władzy publicznej, realizowanie zadań w imieniu własnym i na własną odpowiedzialność, stanowienie przepisów, dysponowanie władztwem administracyjnym.

Odrębność gminy przejawia się we własnych organach, w strukturze, stanowieniu przepisów administracyjnych, sprawowaniu władztwa administracyjnego,

\footnotetext{
${ }^{24}$ M. Kulesza, Niektóre zagadnienia prawne definicji samorządu terytorialnego, „Państwo i Prawo" 1990, z. 1, s. 23.

${ }^{25}$ M. Zdyb, op. cit., s. 25.

${ }^{26}$ A. Wiktorowska, op. cit., s. 82.

${ }^{27}$ W. Jakimowicz, op. cit., s. 207.
} 
we własnym budżecie, w uprawnieniach właścicielskich, zasobach majątkowych. Charakter gminy jako odrębnego podmiotu publicznego został zatem ukształtowany na zasadzie samodzielności, która świadczy o odrębnej od państwa podmiotowości publicznoprawnej.

\section{BIBLIOGRAFIA}

Boć J., Konstytucje Rzeczypospolitej oraz komentarz do Konstytucji RP z 1997 r., Wrocław 1998.

Dybowski T., Mienie komunalne, [w:] Samorzad terytorialny, red. A. Piekara, Z. Niewiadomski, Warszawa 1998.

Europejska Karta Samorządu Terytorialnego sporządzona w Strasburgu dnia 15 października 1985 r. (Dz.U. 1994, nr 124, poz. 607).

Filipek J., Prawo administracyjne. Instytucje ogólne, t. 1, Kraków 1995.

Jakimowicz W., Publiczne prawa podmiotowe, Kraków 2002.

Konstytucja Rzeczypospolitej Polskiej z dnia 2 kwietnia 1997 r. (Dz.U. 1997, nr 78, poz. 483 ze zm.).

Kulesza M., Niektóre zagadnienia prawne definicji samorządu terytorialnego, „Państwo i Prawo” 1990, z. 1.

Kulesza M., O tym, ile jest decentralizacji w centralizacji, a takze o osobliwych nawykach uczonych administratywistów, „Samorząd Terytorialny” 2009, nr 12.

Kulesza M., Wtadza lokalna w systemie reformy gospodarczej, „Państwo i Prawo” 1983, nr 3.

Model władzy lokalnej w systemie reformy gospodarczej, red. M. Kulesza, t. 5, Warszawa 1985.

Orzeczenie Trybunału Konstytucyjnego z dnia 23 października 1995 r., K 4/95, cz. 2, poz. 11.

Przybysz P., Współczesna teoria prawa administracyjnego wobec klasycznych konstrukcji pojęciowych, „Samorząd Terytorialny” 2000, nr 1-2.

Stahl M., Poszukiwania modelu władzy i administracji lokalnej w Polsce, Łódź 1989.

Uchwała Trybunału Konstytucyjnego z dnia 27 września 1994 r., W 10/93, OTK 1994, cz. 2, poz. 46.

Ustawa z dnia 8 marca 1990 r. o samorządzie gminnym (Dz.U. 1990, nr 16, poz. 95).

Ustawa z dnia 27 sierpnia 2009 r. o finansach publicznych (Dz.U. 2009, nr 157, poz. 1240 ze zm).

Wiktorowska A., Prawne determinanty samodzielności gminy. Zagadnienia administracyjnoprawne, Warszawa 2002.

Wójcik S., Samorzad terytorialny w Polsce wXX w. Myśl samorzadowa, historia i wspótczesność, Lublin 1999.

Wyrok Trybunału Konstytucyjnego z dnia 23 września 2003 r., K 20/02, OTK ZU 2003, nr 7A, poz. 76. Zawadzka B., Glosa do orzeczenia TK z dnia 24 stycznia 1995 r., K 5/94, „Państwo i Prawo” 1995, z. 4. Zdyb M., Samorząd a państwo. Nadzór nad samorządem terytorialnym, Lublin 1993.

\section{SUMMARY}

Legal subjectivity of communities is an important matter, since the Second Republic of Poland. In the current legal system legal subjectivity of communities is still the subject of discussion. Although the Constitution does not indicate the formulation of legal subjectivity of communities, however it is clear from the analysis of constitutional rules defining the scope and method of operation. Legal subjectivity of communities is rooted in the Constitution. This act defines communities as a public entity, showing the rules which guarantee its subjectivity.

Keywords: communities; legal subjectivity; public entity; local government unit; local corporation 